\title{
ALBERT TAG V. WILLIAM P. ROGERS ${ }^{1}$
}

$\mathbf{T}_{\mathrm{H}}$ The case arose out of the assertion of legal rights claimed under a treaty that became operative in $1925,{ }^{2}$ to which the United States was one of the enacting parties. The rights were contravened by administrative orders ${ }^{3}$ issued in accordance with an executive order of the President under an act of Congress which entered into operation in $194^{4}$ and by other national legislative acts later in date than the treaty. Article IV of the Treaty of Friendship, Commerce, and Consular Rights, entered into by the United States and Germany, provides that: ${ }^{5}$

Nationals of either High Contracting Party may have full power to dispose of their personal property of every kind within the territories of the other, by testament, donation, or otherwise, and their heirs, legatees, and donees, of whatsoever nationality, whether resident or non-resident, shall succeed to such personal property, and may take possession thereof, either by themselves or by others acting for them, and retain or dispose of the same at their pleasure subject to the payment of such duties or charges only as the nationals of the High Contracting Party within whose territories such property may be or belong shall be liable to pay in like cases.

The Trading with the Enemy Act, as amended, provides that: ${ }^{8}$

During the time of war or during any other period of national emergency declared by the President, the President may, through any agency that he may designate, or otherwise, and under such rules and regulations as he may prescribe, by means of instructions, licenses, or otherwise-

\footnotetext{
${ }^{2} 267$ F.2d 664 (D.C. Cir. 1959), cert. denied, 28 U.S. LAW WEEK 3250.

${ }^{3}$ Treaty with Germany, Dec. 8, 1923, 44 Stat. 2132, as amended by a treaty of June 3, 1935 with respect to provisions not related to the present controversy, 49 Stat. 3258. See also Treaty of Friendship, Commerce and Navigation with the Federal Republic of Germany, Oct. 29; 1954, 7 U.S.T. \& O.I.A. 1839, T.I.A.S. 3593 (effective July 14, x 956 ).

${ }^{3}$ By the Alien Property Custodian, under the Trading with the Enemy Act $\$ 2,40$ Stat. 41I (1917), 50 U.S.C. App. $\$ 2$ (1952), as amended, First War Powers Act, 55 Stat. 838 (1941) 50 U.S.C. App. $\$ \$ 616-20$ (1952). See also War Claims Act of $x 948$ $\S \times 2,62$ Stat. 1246,50 U.S.C. App. $\$ 20 \times 1$ (1952), amending Trading with the Enemy Act. The 1948 act prohibits the return of vested property to certain classifications of German nationals.

'See note 3 supra.

44 Stat. 2132, 2135-36 (1923). (Emphasis added.)

55 Stat. $8_{3} 8,839-40$ (1941), 50 U.S.C. App. $\$ 5$ (1952). (Emphasis added.)
} 
(B) investigate, regulate, direct and compel, nullify, void, prevent or prohibit, any acquisition holding, withholding, use, transfer, withdrawal, transportation, importation or exportation of, or dealing in, or exercising any right, power, or privilege with respect to, or transactions involving, any property in which any foreign country or a national thereof has any interest,

by any person, or with respect to any property, subject to the jurisdiction of the United States; and any property or interest of any foreign country or national thereof shall vest, when, as, and upon the terms, directed by the President, in such agency or person as may be designated from time to time by the President, and upon such terms and conditions as the President may prescribe such interest or property shall be held, used, administered, liquidated, sold, or otherwise dealt with in the interest of and for the benefit of the United States, and such designated agency or person may perform any and all acts incident to the accomplishment or furtherance of these purposes . . .

Under authority of this legislation and of an executive order ${ }^{7}$ of the President, the Alien Property Custodian issued a vesting order ${ }^{8}$ involving property of the appellant in the present case:

All right, title, interest and claim of any kind or character whatsoever of Albert Tag, Heinrich Brunner, his wife and his issue whose names are unknown, and each of them, in and to the Trust Estate created under the Last Will and Testament of Anna Tag, deceased.

Testator was a citizen of the United States, legatee a national of Germany, with which state the United States had been declared by Congress to be at war. ${ }^{9}$

Tag had filed in the Office of Alien Property notice of claim to the property and interests vested, but his claim had been dismissed and the

${ }^{7}$ Exec. Order No. 9095, 7 Fed. Reg. 1971 (1942); U.S. TREAs. Dep'T, DocuMENTs PeRtaining to Foreign Funds Control 83 (1942). Section I establishes "in the Office for Emergency Management of the Executive Office of the President the Office of Alien Property Custodian," to be headed by an Alien Property Custodian ap. pointed by the President. Section 2 confers on the Alien Property Custodian presidential powers authorized by the Trading with the Enemy Act. Section 3 is as follows: "Any property, or interest therein, of any foreign country or a national thereof shall vest in the Alien Property Custodian whenever the Alien Property Custodian shall so direct; and, in the case of any property, or interest therein, subject to the control of the Secretary of the Treasury, when the Alien Property Custodian shall notify the Secretary of the Treasury in writing that he had so directed, the Secretary of the Treasury shall release all control of any such property, or interest therein, to the Alien Property Custodian."

${ }^{8}$ Vesting Order No. 1870,8 Fed. Reg. 10837 (1943), as amended, 8 id. at 11975 . See also, Vesting Order No. 13730,14 Fed. Reg. 5499 (1949).

${ }_{55}$ Stat. 796 (1941). 
time within which to seek a review of the dismissal had expired. In 1958, Tag instituted the present suit in the District Court of the United States for the District of Columbia, making the Attorney General, successor to the Alien Property Custodian, defendant. Not relying upon any procedure prescribed by the Trading with the Enemy Act, he alleged that the provisions of that act pursuant to which the seizure of his property had been made were null and void because in conflict with international law and the above-mentioned treaty enacted by the United States and Germany. The district court, after a hearing, denied Tag's motion for summary judgment and granted defendants' motion for dismissal of the complaint. ${ }^{10}$ He then appealed.

In affirming the action of the district court, the court of appeals ${ }^{11}$ stated that the Trading with the Enemy Act was a war measure "deriving its authority from the war powers of the Congress and of the President" $;{ }^{12}$ also, that it made no distinction between property acquired before or after the beginning of the war. It then took up Tag's contention that there is a practice amounting to what the court describes as "an authoritative declaration of international law," forbidding confiscation of property of enemy nationals during wartime, at least when acquired before the war and "in reliance upon international agreements between the nations concerned. ${ }^{13}$

Whatever efficacy the complainant's reliance on what the court calls "canons of international law" may have had in the absence of other applicable law, namely a provision of the Constitution, a statute, or a

${ }^{10} 267$ F.2d at 665-66.

11 The court consisted of Mr. Justice Burton, retired, sitting by designation pursuant to 28 U.S.C. $\$ 294(a)$, Wilbur K. Miller, and Fahy, Circuit Judges. Opinion by Burton. A petition for certiorari has been filed with the U. S. Supreme Court.

12 267 F.2d at 666 .

${ }^{13}$ Referring in a footnote to The Paquete Habana, 175 U.S. 677 (1900), in which the Supreme Court had held that a peaceful enemy fishing vessel in time of war was exempt from confiscation by reason of international law, the Court of Appeals called attention to the statement in that opinion that there was no applicable treaty or statute to the contrary. It cited the following cases in support of the proposition that Congress had authority to confiscate: Brown v. United States, I2 U.S. 8 (Cranch) I10 (I8I4); Miller v. United States, 78 U.S. 268 (I87I); Stoehr v. Wallace, 255 U.S. 239, 25 I (1921) [Treaty with Prussia of 1799, art. XXIII, 8 Stat. I62, I74 (1799) granting certain rights to the merchants of either country residing in the other when war comes, held inapplicable]; White v. Mechanics Sec. Corp., 269 U.S. 283 (I925) [stating that disposition of enemy funds under the Trading with the Enemy Act was recognized in the World War I Peace Treaty with Germany, 42 Stat. I939 (x92x)]; United States v. Chemical Foundation, Inc., 272 U.S. I (I926) (referring to the last-mentioned treaty, holds that the Trading with the Enemy Act should be liberally construed to effect its purposes). Reference is also made to Markham v. Cabell, 326 U.S. 404, 413 (1945). 
treaty, "14 "the federal courts are bound to recognize any one of these three sources of law as superior" thereto. "There is no power in this Court to declare null and void a statute adopted by Congress or a declaration included in a treaty merely on the ground that such provision violates a principle of international law. ${ }^{315}$

There was, of course, no question of any lack of harmony between international law and the treaty in the case before the court. [T] he freedom of German nationals to dispose of their properties in the United States, under the Treaty" enacted by Germany and the United States in the I920's, was, however, found by the court to be "in conflict with" the Trading with the Enemy Act, as amended in the 1940's. ${ }^{10}$ The issue thus was "whether subsequent Acts of Congress shall be recognized ... rather than earlier conflicting provisions of a treaty."17 The court then rejected complainant's contention that the treaty precluded the amendatory legislation, "at least insofar as such legislation would authorize the seizure and confiscation by the United States of property of its enemies who, as individuals, had acquired the property before World War II in . reliance upon treaty provisions entered into before the war."18

The court then asserted that "it has long been established that treaties and statutes are on the same level and, accordingly, that the latest action expresses the controlling law."119 In support of its assertion, the court cited three nineteenth-century Supreme Court decisions. ${ }^{20}$ It did not cite any decision on this point later than $1889 .{ }^{21}$

\footnotetext{
${ }^{14}$ Here should be noted U.S. CoNST. art. VI, § 2: "This Constitution, and the Laws of the United States which shall be made in Pursuance thereof; and all Treaties made, or which shall be made, under the Authority of the United States, shall be the supreme Law of the Land ...."

${ }^{15} 267$ F.2d at 666 .

${ }^{10} 1 d$. at 667 .

${ }^{17}$ Ibid.

${ }^{18}$ Ibid.

${ }^{10}$ Ibid.

${ }^{20}$ The Chinese Exclusion Case, 130 U.S. 581 (1889); The Head Money Cases, 112 U.S. 580 (1884); The Cherokee Tobacco, 78 U.S. 616 (1871). An uncited recent decision of the Federal District Court for the District of Columbia, Pauling v. McElroy, 164 F. Supp. 390 (1958), relating to the Atomic Energy Act of 1954, 68 Stat, 919 (1954), 42 U.S.C. $\S \S 2011-81$ (Supp. V, 1958) though citing no precedents, likewise follows these nineteenth century cases. An appeal has been taken from this decision.

${ }^{21}$ There are, however, important mid-twentieth century cases, notably Cook v. United States, 288 U.S. 102 (1933), and Bill Co. v. United States, so4 F.2d 67 (1939), which considerably modify the former holdings. The Supreme Court in the Cook case held that a treaty would not be adjudged to be modified by a subsequent act of Congress unless Congress' intention to overrule the treaty was clearly indicated.
} 
Apart from the decisive invocation of the doctrine posteriores priores with reference to treaties and statutes, however, the court does bring into its discussion at least three significant factors. The first is manifest in the following passage relating to the German-United States treaty. effective in $1925^{: 22}$

The Treaty did not state whether . . freedom [to retain or dispose of property] would be effective in time of war between the contracting parties. However, the [Unted States] Government in arguing this case has assumed that Article IV was applicable in time of war as well as in peace. We, accordingly, have made the same assumption.

The second significant factor referred to appears in the penultimate paragraph of: the opinion as follows: ${ }^{23}$

There is a further material consideration. The 1952 Bonn Convention, àmong other things; provided that the Federal Republic of Germany thereafter would raise no objections against measures taken or to be taken with regard to property "seized for the purpose of reparation or restitution, or as a result of the state of war....24 It provided also that German nationals thereafter would not assert claims of any description against the allies or their. nationals arising out of actions taken or authorized by such allies because of the existence of a state of war in Europe. In fact, the Bonn Convention gave support to Allied High Commission Law No. $63 .{ }^{25}$ That law provided that the right, title and interest of German nationals in German external assets were extinguished as of the time of their vesting. 'Germany further guaran-. teed in the Bonn Convention that it would compensate the former owners of property so seized. ${ }^{26}$ The final action in this field is found in the 1956 Treaty

${ }^{22} 267$ F.2d at 667 . See also note 23 infra. While the courts have long tended to pronounce such ordinarily legal questions as whether a treaty remains in froce to be "political," this quotation from the court's opinion in the present case seems perhaps to leave merely to the government's attorneys the determination of a question examination of which by the court, together with an inquiry into the intention of the parties, might have led to the avoidance of conflict found to exist between treaty and statute, which finding was inseparable from a breach of good faith by the United States. No mention of the wellknown legal maxims that treaties should be liberally interpreted to preserve their integrity, and that every effort should be made to find concurrence and avoid conflict between laws, is found in the present opinion.

${ }^{23} I d$. at 668-69. See note 22 supra.

at Convention on the Settlement of Matters Arising out of the War and the Occupation (Bonn Convention), May 26, 1952, as amended by Schedule IV to the Protocol on the Termination of the Occupation Regime in the Federal Republic of Germany, signed at Paris on Oct. 23, 1954, 6 U.S.T. \& O.I.A. 5652,5670, T.I.A.S. 3425 . Footnote by the court.

${ }^{25}$ Official Gazette of the Allied High Commission for Germany, No. 64, Sept. 5, 1951, pp. I 107-riro. Footnote by the court.

${ }^{20} \mathrm{Ch} .6$, art. 5 of the Bonn. Convention. 
of Friendship, Commerce and Navigation between the United States and Germany. ${ }^{27}$ This reaffirmed the provisions of the Bonn Convention and added to them further agreement of complete co-operation.

Finally, significance is readily discernible in the court's remark: ${ }^{28}$

If Congress adopts a policy that conflicts with the Constitution of the United States, Congress is then acting beyond its authority and the courts must declare the resulting statute to be null and void. When, however, a constitutional agency adopts a policy contrary to a trend in international law or to a treaty or prior statute, the courts must accept the latest act of that agency.

The "constitutional agency" which the court had in mind was presumably the Office of Alien Property. Its act found to be in contravention of the German-United States treaty which had been law for some twenty years was on the basis of an intervening executive order based on an intervening legislative statute, which had necessarily to be in accord with the provision of the Constitution requiring that the Constitution, laws made in pursuance thereof, and treaties (without any stated distinction) should be the Supreme Law of the Land. ${ }^{20}$

\footnotetext{
${ }_{7}^{27}$ U.S.T. 1839 , 1919, 1928 , T.I.A.S. No. 3593. Footnote by the court.

${ }_{28}^{28}$ F.2d at 668 . (Emphasis added.)

${ }^{29}$ The question arises whether a mere administrative agency either should, as a matter of policy, or can, as a matter of constitutional or world law, be accorded the authority to determine that a treaty shall be set aside and its own ruling as determined by itself prevail. See note ${ }_{4} 4$ supra.
} 